\title{
Centennial Congress of the International Society for the History of Medicine
}

The International Society for the History of Medicine (ISHM) is a non-profit international society with the aim to assist and support the historical study of all questions relating to the medical and allied sciences. The Society stimulates and oversees the organisation of periodic international congresses in the history of medicine. (ISHM Statutes, 2007)

For the first time in the one hundred year history of the ISHM, the congress took place in Latvia. Although, during preparations for the congress, we found confirmation that in the mid-1950s, Professor Pauls Stradin̄š (1896-1958) became a member of the ISHM and in 1958 intended to invite, from the high tribune of the $16^{\text {th }}$ Congress of ISHM in Montpellier, all members of the society for the opening of the museum of the history of medicine in Riga. (Sondervorst, 1959) His death in August 1958 did not allow these plans to be fulfilled. And only in 2021, with a distance of 63 years, did his idea become a reality.

As it was written in the previous issue of Acta medico-historica Rigensia, the virtual opening of the Congress took place as scheduled on 24 August 2020. The Riga Congress was seen as the inauguration event of the celebration of the centenary since the creation of the ISHM in 1921 in Paris. (Garnizone \& Salaks, 2020)

\section{Online lectures "Members to Members"}

There were 365 days between the opening ceremony of the congress in 2020 and the continuation of the congress on 23 August 2021. Therefore, for the first time, the organisers had the challenging task of maintaining the interest of the participants and ensuring the continuation of knowledge in the field of history of medicine. 
October 2020 started with online lectures under the common title "Members to Members" and the later discussion. Among the first speakers was Professor Florian Steger from the University of Ulm in Germany. His main research fields include questions of history, philosophy, and ethics of medicine. (Steger, 2021) The lectures of Professor Steger and his colleague Dr Marcin Orzechowski concerned politicised medicine.

During the winter and spring, online lectures were held by: Professor Tatiana Sorokina from the People's Friendship University of Russia in Moscow, Professor Emeritus Avi Ori from Tel Aviv University, Professor Yoel Donchin from Hebrew University of Jerusalem, Associate Professor Maria Sergeeva and Associate Professor Evgeniya Panova from Sechenov University in Moscow. (ISHM Newsletter, 2021)

\section{Summer School on the History of Medicine}

In 2017, Rīga Stradiñš University (RSU) Institute of History of Medicine offered to organise and conduct the first summer school in the history of medicine for young scholars a week before the 47th ISHM Congress in Riga. The ISHM, RSU and Hoffmann-La Roche became the sponsors of the first summer school in the history of medicine. Only nine participants were selected from the applicants. Due to the pandemic, the summer course was moved online and occurred once a week on the Zoom platform from 1 July to 12 August 2021. The summer course was conducted by invited guest lecturer Professor Emerita Jacalyn Duffin from Queen's University in Kingston (Canada). (News: $1^{\text {st }}$ ISHM Summer School ..., 2021) She offers more than 20 of her scientific research topics for the school participants to select from. Students voted for and chose the following 5 topics:

- Plagues and Peoples: Epidemic Diseases in History.

- First, Do No Harm: History of Treatment, Pharmacology, and Pharmaceuticals.

- Poisoning the Spindle; the discovery of Vinca alkaloids.

- Palliative Care: The Oldest Profession?

- Medical Miracles: Doctors, Saints, and Healing through the Vatican Archives.

Participants were from Latvia, Lithuania, Russia, Germany, Italy, Portugal, Israel, China and Mexico. All of them were granted a certificate to participate in the 47 ${ }^{\text {th }}$ ISHM Congress scientific events (23-27 August 2021) without a fee, online or onsite. Two of the summer school students 
were invited to be moderators of the poster sessions of the congress and successfully handled the role entrusted to them in the congress programme. Based on the results of the first school in the history of medicine, it was decided to continue this project of the ISHM and the RSU and to conduct subsequent schools with the participation of guest lecturers from the society on the eve of each subsequent congress and in the country hosting the congress. The society sees this as an opportunity to attract young researchers to become members of the ISHM.

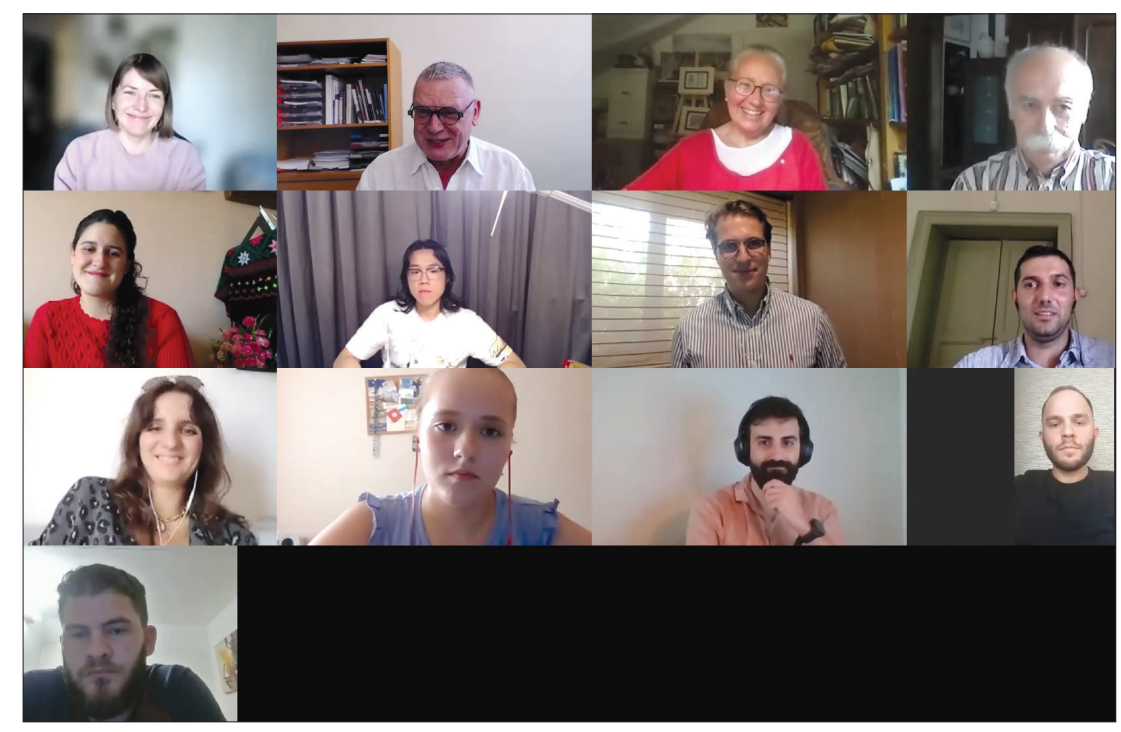

Clossing Zoom session of the $1^{\text {st }}$ Summer School on the History of Medicine. Photo by Aldis Erglis

\section{Pre-congress symposium "Bridging the Baltic"}

This satellite symposium was organised by the Heinrich-Heine University Düsseldorf, Rīga Stradiņš University, Odense University, and Lund University. The network 'Bridging the Baltic: Medicine in the Baltic Sea Region' brings together researchers who currently work on aspects of medical history in the Baltic Sea region to illuminate currents of ideas and areas of cooperation and conflict. One main theme of the network concerns how the circulation of knowledge in medicine played out during the Cold War. How did science exchange in medicine work across the Iron Curtain? 
The Riga meeting has also been characterised by interdisciplinarity with speakers from different fields, such as historians, physicians, scholars of other medical studies, health care economists, politicians, and diplomats. The symposium was supported by the German Research Foundation and the European Association for the History of Medicine and Health. (Hansson, 2021)

\section{Hybrid Congress of ISHM}

For the delegates of the congress around the world, this year has been challenging, and full of learning to adapt to social distancing and online environments. No matter how much everyone missed meeting face-to-face, it became clear that not all of them could travel and meet on site. The RSU technical support team and the professional broadcast company joined the organisers to ensure that the congress could be simultaneously held onsite and online. 48 delegates who were able to travel (EU certificate of full course of vaccination) came to the congress and visited onsite, while others joined online. All sessions were held at the reconstructed RSU Anatomy Museum in Riga.

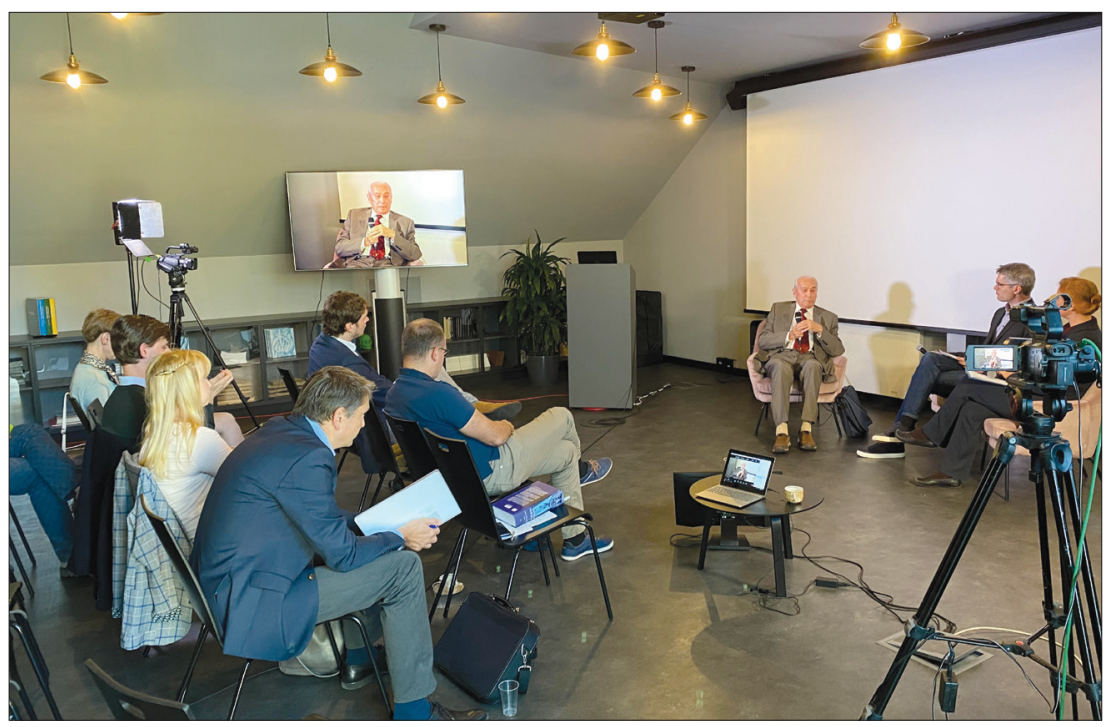

Interview with former Minister of Foreign Affairs of the Republic of Latvia, Dr Georgs Andrejevs. Photo by Juris Salaks 


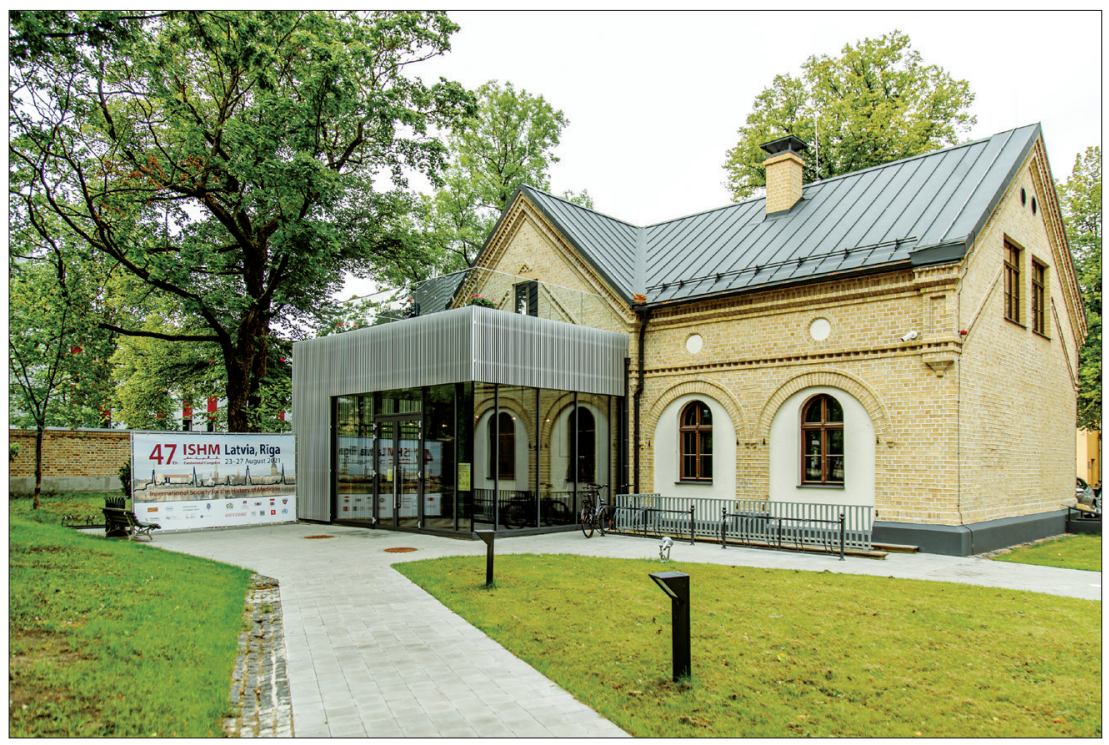

RSU Anatomy Museum - the venue of the 47th ISHM Congress.

Copyright holder $R S U$

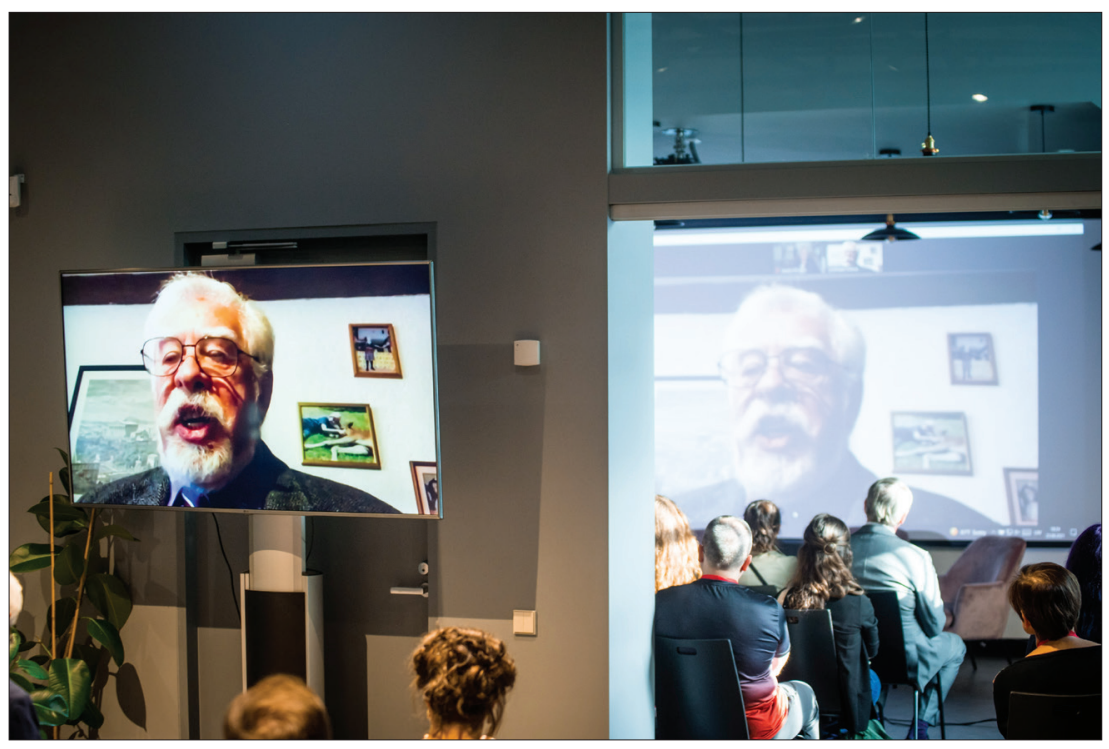

Welcome address by the President of ISHM, Professor Carlos Viesca.

Copyright holder RSU 
During each session, participants were able to present either onsite or online. All panels, scientific sessions, and main ceremonial events were broadcast live on the congress website for all delegates, but four plenary lectures were broadcast for free through the congress website and two Facebook channels.

Seven days of the Centennial 47th ISHM Congress in Riga were held with 4 plenary sessions, 3 panel discussions, 8 scientific sessions, 2 poster sessions, 2 satellite symposiums "Bridging the Baltic" and "Anatomy \& Beyond", as well as an extensive social programme. It was a very intense week for the delegates who were able to attend the congress onsite in Riga and no less busy for the delegates online with 38 hours of broadcasts from various scientific platforms of the congress.

\section{Invited keynote speakers}

Long before the opening of the $47^{\text {th }}$ Congress, an agreement was reached with invited key speakers for 4 plenary sessions, and each lecture was announced in advance on the homepage of the congress. Unlike previous congresses, the opportunity to listen to lectures on the spot or online in webinar mode via the congress webpage and Facebook channels was not only for the congress delegates, but also for everyone who found the announced topics interesting. Therefore, the online audience during live broadcasts ranged from 390 to 630 people.

Professor Emerita Jacalyn Duffin (Canada) is a haematologist and historian who held the Hannah Chair of the History of Medicine at Queen's University from 1988 to 2017. A former president of both the American Association for the History of Medicine and the Canadian Society for the History of Medicine, she is the author or editor of eleven books and many articles and holds several awards for teaching and research. The third edition of her book "History of Medicine: A Scandalously Short Introduction"1 was published in 2021. A supporter of the medical humanities, she has been a contributing editor of the online Literature, Arts, and Medicine database since 1995. Her research focuses on disease, technology, religion and health policy. She runs an activist website for the current drug shortage problem and a collaborative translation project for the $17^{\text {th }}$ century Latin author,

1 Duffin, Jacalyn. History of Medicine: A Scandalously Short Introduction. Third edition. University of Toronto Press, 2021, p. 560. 
Paolo Zacchia. (Duffin, 2021) Her most recent research was on the history of the Medical Expedition to Easter Island, led by Canada in 1964-1965, about which she spoke in Riga: Stanley's Dream: “The Medical Expedition to Easter Island".

Nils Hansson (Germany), Ph.D., is an associate professor in the Department for the History, Theory and Ethics of Medicine at the Heinrich Heine University of Dusseldorf. His scholarly interests include the enactment of excellence in medicine esp., The Nobel Prize, The Gender Award Gap in Medicine, Knowledge Transfer in the Baltic Sea region. He co-edited the volumes "Attributing Excellence in Medicine - The History of the Nobel Prize", Brill (2019) and "Explorations in Baltic Medical History, 1850-2015", Rochester Studies in Medical History (2019). Hansson has organised Nobel Prize symposia at Harvard Medical School, McGill University, Charité University Hospital Berlin, and Berne University. He received several awards for his Nobel Prize research, e.g., the Axel Hirsch Prize in 2017 and the Bengt Lindskog Prize in 2019. (Bengt-LindskogPrise, 2019) His plenary lecture was: "How (not) to Win the Nobel Prize: Winners and Losers in Nobel Prize History".

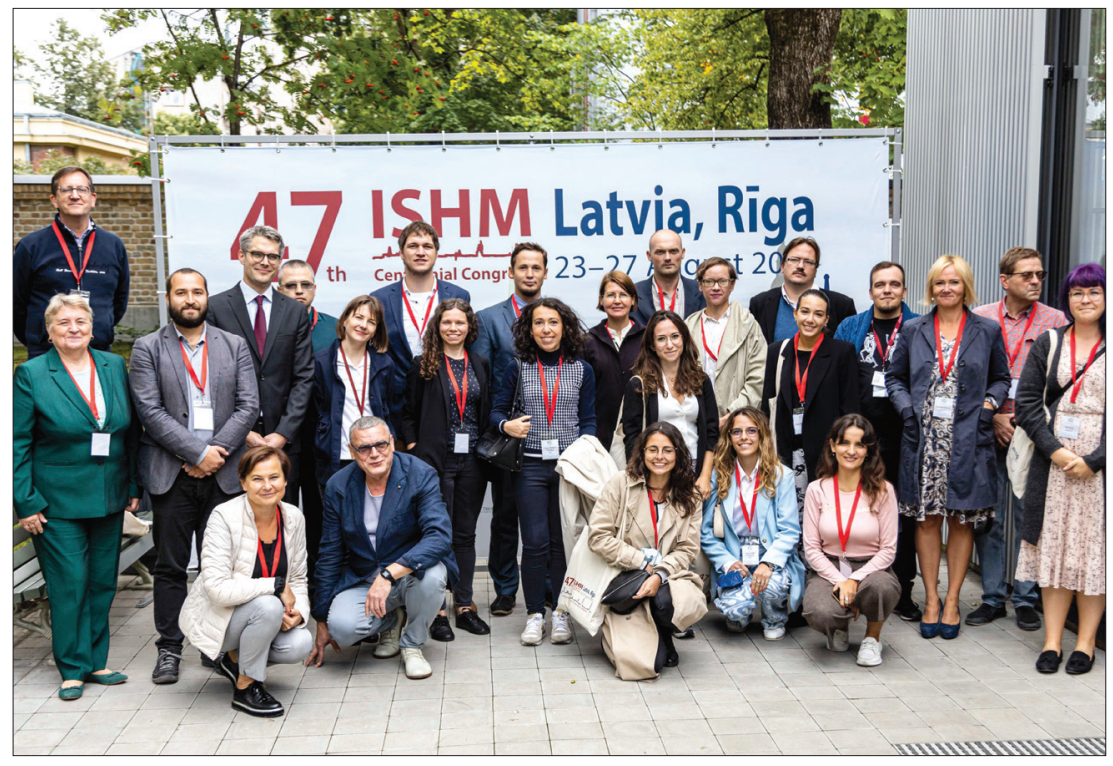

On-site participants of the Congress.

Copyright holder RSU 
Dan Healey is a professor of Modern Russian History at the University of Oxford. He has explored the history of homosexuality in tsarist and Soviet Russia. In his book "Russian Homophobia from Stalin to Sochi" (Bloomsbury Academic, 2018), he looks at the recent politics of homophobia in Russia from a historical perspective.

He has written a monograph on early Soviet forensic medicine, chapters, and articles on forensic psychiatry, and numerous articles on the history of gender and sexuality in modern Russia.

Healey has long had an interest in the Soviet Gulag forced-labour camp system, and in particular, its medical services and their history. His current project explores the organisation and practice of medicine in Stalin's forced labour camp system, the 'Gulag Archipelago'. The Soviet camps spanned the length and breadth of the Soviet Union, and the Gulag became a byword for cruelty and human degradation. Yet, archival sources from the camp system itself reveal the operation of an extensive and surprisingly sophisticated medical service. Embedded in the organisation of the secret police who ran the camps, the Gulag's medical clinics, stations and hospitals present a puzzle for the historian: Why have these places of apparent humanity in the midst of suffering and high mortality? In this talk, Healey focuses on published and unpublished memoirs of doctors and nurses, museum collections, and reminiscences of prisoner-patients and prisoner-medics, to illuminate the experience of medical workers in Stalin's penal system. (Healey, 2021) Title of his plenary lecture: “The Notebooks of Gulag Doctors: Medical service in Stalin's Labour Camps".

Alexander Lukas Bieri has been the curator of The Roche Historical Collection and Archive for more than twenty years. He is responsible for the in-house museums, collections, and archives that include major assets on the history of pharmacy, medicine, and art (and an anatomical collection). His publications include works on art and architectural history as well as on the history of science and business. He is currently chairman of the International Council on Archives' Section on Business Archives and of the German Business Archivists Association's Section on Archives of the Chemical and Pharmaceutical Industry. Alex is also a member of ICOM Switzerland and in this capacity a specialist for $20^{\text {th }}$ century interior design. Based on a rare find in one of Roche's collections, he developed an interest in the danse macabre a long time ago. He found out that the art form 
of the danse macabre offers a fascinating insight into the artistic development of the depiction of humans. It also allows one to highlight the transformative power that Andreas Vesalius' "De Humani Corporis Fabrica" had on art in its time and beyond. Furthermore, the history of danse macabre makes changing societal attitudes toward death understandable. (Bieri, 2021) His lecture: "Andreas Vesal's Lasting Impact on the Art of Danse Macabre" was a joint plenary session lecture for the $47^{\text {th }}$ ISHM Congress and a satellite symposium "Anatomy \& Beyond".

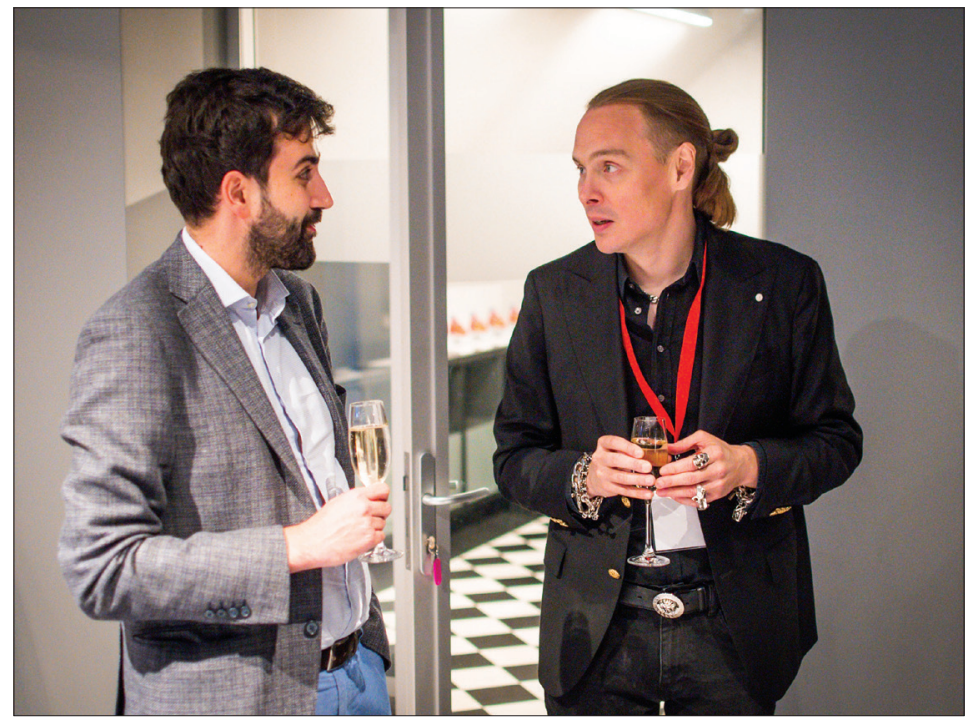

Keynote speaker Alexander Lukas Bieri and the student of the Summer School for the History of Medicine Agostinho Sousa.

Copyright holder RSU

\section{Panel discussions}

The $47^{\text {th }}$ ISHM Congress also offered all delegates 3 panel discussions with a team of experts and an appointed moderator for each panel session. It was a useful way to trigger an exchange of views among experts and to provide answers to the audience. All panels followed the plenary lectures, which were related to the key speaker topic and took place onsite with invited experts onsite and online. The first panel discussion was moderated by Nils Hansson (Heinrich Heine University, Dusseldorf) on 
the topic "Gender Award Gap? (In)visibility of women in medical recognition and award culture." Panelists: Marika Garnizone (Latvia), Jacalyn Duffin (Canada), and Jocalyn Clark (UK). Another panel was used as a joint event with the satellite symposium "Anatomy \& Beyond" and covered the topic "Death and Beyond". In the role of moderator, the coordinator of the government administration of the city of Brussels Alya Dirix (Belgium/Greece) was selected. Her experts underline more specific themes, like "Dealing with the Dead - Sentiment versus Modernity" by anatomist and Gordon Museum curator William Edwards (UK), "Should humans from the past exist as digital humans in the future?" by Mark Roughley (UK) and diplomat and writer Theo Dirix (Belgium / Greece) covered the topic "How would Sophocles's Antigone bury and rebury her brother tomorrow?". The last panel was in between the Dan Healye plenary lecture and the two last breakout sessions, and united by the title "Medicine and Totalitarianism". The moderator on site was Florian Steger from Ulm University with two panelists, Marcin Orzechowski (Germany), Ineta Lipša (Latvia). The topic already attracted attention during the preparation of the congress and was extensively presented in fixed speeches of the congress delegates.

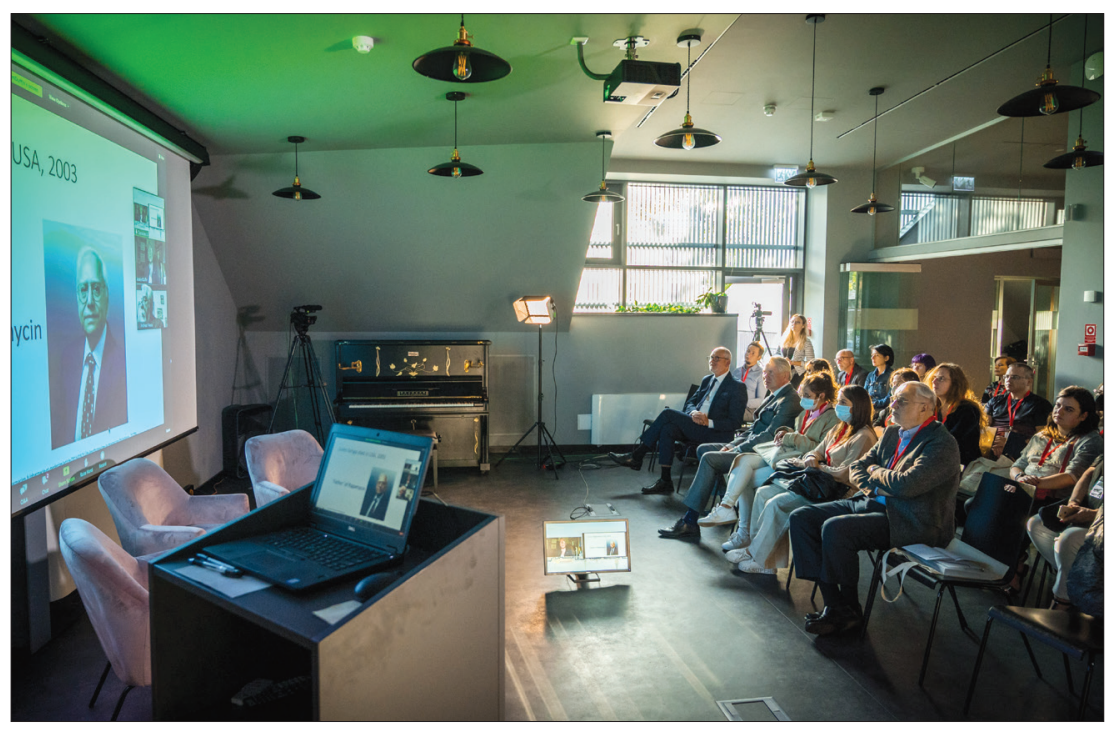

On-site participants of the Congress.

Copyright holder RSU 


\section{Satellite symposium "Anatomy \& Beyond"}

Symposium "Anatomy \& Beyond" was a collaborative project of the Association Européenne des Illustrateurs Médicaux et Scientifiques (AEIMS), The Medical Artists' Association of Great Britain (MAA), Biological and Medical Art in Belgium (BIOMAB), Art Researches Science International Collaboration (ARSIC), International Society for the History of Medicine (ISHM), and the RSU Anatomy Museum. The event is supported by the Embassy of Belgium to Sweden and Latvia, General Representation of the Government of Flanders in Poland and the Baltic States, Vesalius Trust and Honorary Consul of Belgium in Latvia, Dr. Didzis Gavars.

The symposium "Anatomy \& Beyond" explores new ways to envisage the role of art and anatomy, reimagining humanity on earth and beyond: in the here and now and in possible post-terrestrial futures. Artists, anatomists, scientists, medical doctors, and museum curators are forced to rethink the porous limitations of our organic earthbound bodies and the role to be played by advancements and revolutionary technological physical enhancements to our bodies that are occurring with ever gathering speed as we venture into new arenas and space. (Anatomy \& Beyond, 2021)

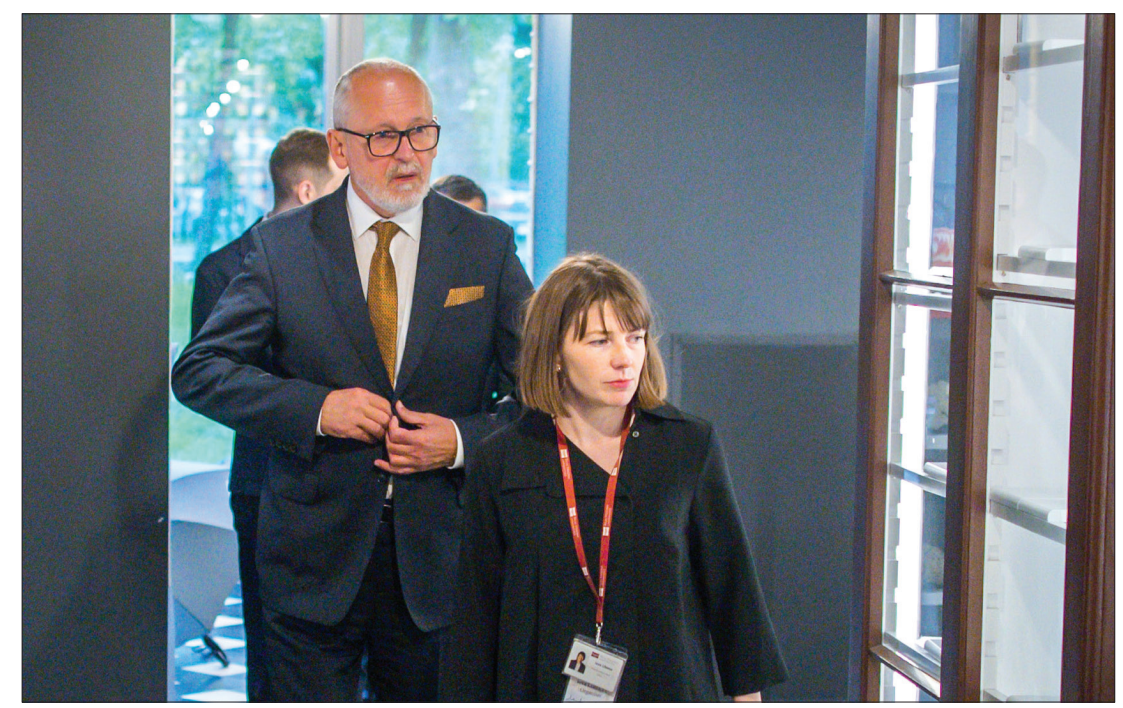

Congress Honorary President, Rector of the Rīga Stradiņ̌ University, Professor Aigars Pētersons accompanied by the Congress General Secretary Ieva Lībiete. Copyright holder RSU 
One-day symposium was closed with the vernissage of the "Anatomy \& Beyond" exhibition of artworks of seven artists: Andrew Carnie (UK), Eleonor Crook (UK), Joe Davis (USA), Bryan W. Green (UK), Mara G. Haseltine (USA), Pascale Pollier (UK/BE), and Nina Stellars (AU). It is a sequel to Pascale Pollier's successful and inspirational touring exhibition: Fabrica Vitae, and the accompanying conference Vesalius Continuum, of which she was the curator and chief organiser.

\section{Mark Mirsky Prize: a new award for historians of medicine}

In honour of the leading Russian historian of medicine, Professor Mark Mirsky (1930-2010), his family, in cooperation with ISHM has established a new research award in 2021. The Mark Mirsky Prize will mostly be awarded for important scientific works in the field of the history of medicine at each congress of ISHM starting from the $47^{\text {th }}$ ISHM Congress in Riga. The cash prize is 3000 euros. The laureate will be selected by the scientific board of the congress.

Professor Mark Mirsky was a long-time full member of the International Society for History of Medicine and served as chairman of many scientific sessions of ISHM congresses and meetings. He was a fervent supporter of the humanities and a sharp expert in the history of medicine. The ISHM honours his dedication and thanks his family members who sponsored the Mark Mirsky Prize for the first time this year, by naming the ISHM Award Diploma in his honour. In addition, he was a frequent visitor to Riga and always maintained professional contacts with the members of the Latvian Association of Medical Historians.

The award ceremony took place during the closing ceremony of the $47^{\text {th }}$ ISHM Congress in Riga for the first time. Professor Mark Mirsky's son, Professor of the Brandenburg University of Technology, Vladimir Mirsky, and his wife visited Riga to attend the award ceremony. The first ever Mark Mirsky prize was given to Assistant Professor Ieva Lỉbiete from Rīga Stradin̄š University for her research presented at the congress: "A Description of Syndromic Cryptophthalmos by Poet Daniel Hermann in "De monstroso Partu..." published in Riga, 1596". A diploma and a symbolic cheque for 3000 euros were presented to Ms Ieva Libiete by Professor Vladimir Mirsky. 


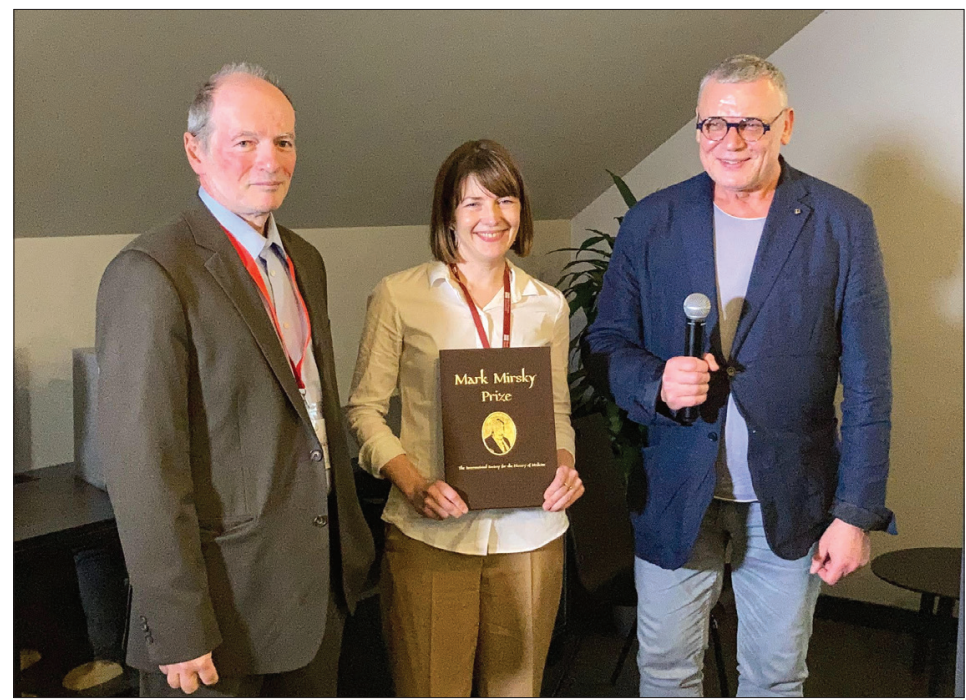

Professor Mark Mirsky first award ceremony. From the left: Vladimir Mirsky, Ieva Lībiete, Juris Salaks. Photo by Aldis Erglis

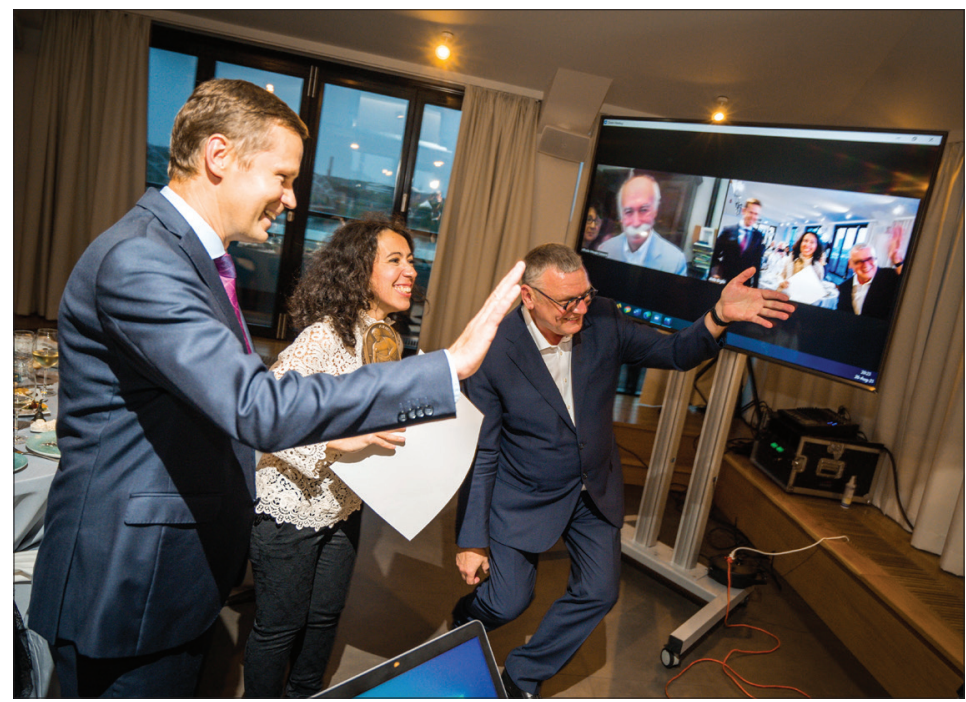

Professor Pauls Stradiņš award virtual ceremony.

From the left: Pēteris Stradiņš, Laura Musajo Somma, Juris Salaks; on the screen Alfredo Musajo Somma. Copyright holder RSU 
Later, the laureate of the first Mark Mirsky award sent the Treasurer of the ISHM a request to transfer the entire amount of the prize to the account of the Medical Museum's Endowment Fund in Riga to support young medical historian scholars.

Another award, the Professor Pauls Stradiņš Prize, was presented virtually to Professor Alfredo Musajo Somma during the Gala dinner of the congress on 26 August 2021. The award was given to Professor Alfredo Musajo Somma for his contribution to strengthening the role of Latvia, the Latvian Association of Medical Historians, Rīga Stradiņš University and Pauls Stradiņš Museum of the History of Medicine among medical historians on an international scale. The bas-relief and diploma were transferred to Bari by the daughter of the Stradiņš Prize winner - Dr Laura Musajo Somma.

$* * *$

In the closing speech, President of the $47^{\text {th }}$ ISHM Congress, Professor Juris Salaks said:

"I would like to thank all the Committees of the Congress for their work in preparing the event in unusual conditions, all the members of the ISHM who supported the Congress by participating on-site in Riga or online, the outstanding key speakers, moderators of panel discussions and sessions chairs, the Rīga Stradiňš University for the opportunity to hold our convention in the hospitable premises of the New Museum of Anatomy and technological support, as well as all the partners and sponsors that have made the Congress special and worthy of the ISHM century."

The $48^{\text {th }}$ Congress of the ISHM will take place next year in Iaşi, Romania.

\section{References}

Anatomy \& Beyond (2021), “About". Retrieved from https://www.anatomy-and beyond.com/about [accessed 5 Nov 2021].

Bengt-Lindskog-Preis für PD Dr. Nils Hansson (2019), Exzellenzforschung, [Heinrich-Heine-Universität Düsseldorf web site]. Retrieved from https:// www.hhu.de/en/about-hhu/press-and-marketing/current-news/press-releases-hhu/news-detailansicht/bengt-lindskog-preis-fuer-pd-dr-nils-hansson [accessed 5 Nov 2021]. 
Duffin, J. (2021), About, [Jacalyn Duffin home page]. Retrieved from https:// jacalynduffin.ca/ [accessed 5 Nov 2021].

Garnizone, M., \& Salaks, J. (2020), 'The International Society for the History of Medicine begins the celebration of its 100th anniversary in Latvia,' Acta medico-historica Rigensia, vol. 13 (32), pp. 93-103. doi:10.25143/amhr.2020. XIII.06

Hansson, N. (2021), 'History of Medicine in the Baltic Sea region: Introductory remarks by the Editor,' Acta medico-historica Rigensia, vol. 14 (33), pp. 7-9.

Healey, D. (2021), Meet the speakers, [47-th ISHM Congress home page]. Retrieved from https://ishm2020.rsu.lv/dan-healey [accessed 5 Nov 2021].

ISHM Newsletter. Spring (2021), "Members to Members" ISHM members' lectures online, spring session, Spring edition, 2021.

ISHM Statutes. By-laws adopted by the General Assembly (2007), Article 2, [The International Society for the History of Medicine]. Retrieved from https://www.biusante.parisdescartes.fr/ishm/eng [accessed 5 Nov 2021].

News: 1st ISHM Summer School on the history of medicine (2021) [47th Congress of ISHM]. Retrieved from https://ishm2020.rsu.lv/news/1st-ishm-summerschool-history-medicine [accessed 5 Nov 2021].

Sondervorst, F. A. (1959), Paul Stradin. In: Bulletin et Mémoires de la Société Internationale d'Histoire de la Médicine, 1, 4. 30.

Steger, F. (2021), Mitarbeiter des Instituts für Geschichte, Theorie und Ethik der Medizin, [Universität Ulm web site]. Retrieved from https://www.uni-ulm. $\mathrm{de} / \mathrm{med} / \mathrm{gte} / \mathrm{mitarbeiter/mitarbeiter/steger-florian-univ-prof-dr/} \mathrm{[accessed}$ 5 Nov 2021].

\section{Marika Garnizone}

RSU Medicīnas vēstures institūts, Latvija /

RSU Institute of the History of Medicine, Latvia

Juris Salaks,

Profesors, RSU Medicīnas vēstures institūts, Latvija /

Professor, RSU Institute of the History of Medicine, Latvia 